\title{
OSMOTIC DEHYDRATION OF YACON SLICES: EFFECT OF DIFFERENT POLYOLS ON MASS TRANSFER PARAMETERS
}

\author{
K. S. MENDONÇA, J. R. de JESUS, M. C. A. PEREIRA e J. L. G. CORRÊA \\ Universidade Federal de Lavras, Departamento de Ciência dos Alimentos \\ E-mail para contato: jefferson@dca.ufla.br
}

\begin{abstract}
The aim of this study was to evaluate the parameters of mass transfer in the dehydration of yacon slices with different polyols as osmotic agents. The samples were immersed on hypertonic solutions ( $40^{\circ}$ Brix) of xylitol, maltitol, erythritol, isomalt and sorbitol at $25^{\circ} \mathrm{C}$. The kinetics of solid gain (SG), water loss (WL) and water activity $\left(\mathrm{a}_{\mathrm{w}}\right)$ of the yacon slices were evaluated over 120 minutes of osmotic dehydration. The effective diffusion coefficients of water and solids were calculated by the diffusive model of Fick. The results showed that the SG was greater in samples treated with solutions of erythritol and lower in isomalt and maltitol solutions. Samples immersed in solutions of sorbitol and xylitol showed intermediate SG. The samples treated in solutions of sorbitol, xylitol and erythritol presented higher water diffusion coefficients and were more effective at reducing parameters of WL and $\mathrm{a}_{\mathrm{w}}$ than the other polyols. The model of Fick represented well the differences between the kinetics of WL and SG for the tested polyols.
\end{abstract}

\section{INTRODUCTION}

Yacon is an eatable root originally from the Andean region of South America. Due to its prebiotic properties, high content of fructooligosaccharides and low glycemic index, this tubercle has been studied for controlling diseases as obesity and diabetes (Pereira et al., 2013).

The development of processing techniques to increase the shelf life of yacon and improve its selling is important because it could allow the availability of the tubercle all-over the year and by pass its perishability. On one hand, drying is a common method for food conservation. On the other hand, the exposure to high temperatures for long periods in drying process decrease the prebiotics, nutritional and sensory content of yacon (Lenart and Dabrowska, 1999). The osmotic dehydration (OD) is a pretreatment to drying that could aid to preserve the physical, chemical and nutritional characteristics of the dehydrated product with respect to the fresh one (Mujumdar and Law, 2010; Ferrari et al., 2011; Vieira et al., 2014).

The OD process is function of the gradient of chemical potential between the product and the osmotic solution. The higher the difference of the water activity between the solution and the food, the higher the dehydration (Labuza, 1975). Factors like the nature and the molecular 


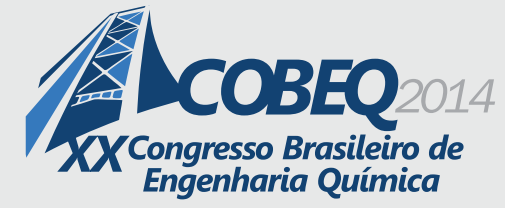

19 a 22 de outubro de 2014

Florianópolis/SC

weight of the osmotic agent and the concentration of the solution define the water activity of the solution. Solutions of polyols are widelly employed as osmotic agent (Sritongtae et al., 2011; Chauhan et al., 2011). Due to their low caloric value, they are suggested as alternative ingredient for food for diabetics and obese people.

The goal of this work was the evaluation of the mass transfer kinetics of five different polyols (xylitol, maltitol, erythritol, isomalt and sorbitol) with the aid of the diffusive model of Fick. The kinetics of water activity was also evaluated.

\section{MATERIALS AND METHODS}

\subsection{Material}

Yacon roots (Smallanthus sonchifolius) were obtained in the local market (Lavras, Minas Gerais state, Brazil). The tubercles were washed, manually peeled and cut into slices of $2.00 \mathrm{x}$ $2.00 \times 0.50 \mathrm{~cm}$ with the aid of a form and a stainless knife. After cutting, the slices were soaked for 3 minutes in a solution of citric acid 1\% (weight/volume) to avoid enzymatic browning (Reis et al., 2012). The fresh yacon presented average moisture content of $92.93 \pm 1.15 \%$ (wet basis) and water activity $\left(a_{w}\right)$ of $0.985 \pm 0.001$. These values are close to those observed in the literature (Lago et al., 2012; Pereira, et al., 2013).

The slices were then immersed in the osmotic solutions at $40{ }^{\circ} \mathrm{B}$. The relation roots:solution ratio was about 1:10 (w/w) to avoid dilution of the solution (Vieira et al., 2014) and the temperature was maintained at $25{ }^{\circ} \mathrm{C}$ in a climate controlled chamber. Five different solutions (xylitol, maltitol, erythritol, isomalt and sorbitol) were evaluated as osmotic agents. The molecular weight of different polyols and the water activity of their solutions at $40{ }^{\circ} \mathrm{B}$ are shown in Table 1.

Table 1 - Molecular weight of polyols and the water activity of their solutions at $40{ }^{\circ} \mathrm{B}$

\begin{tabular}{|l|l|l|}
\hline Osmotic Agent & Molecular weight ${ }^{*}\left[\mathrm{~g} \cdot \mathrm{mol}^{-1}\right]$ & Water activity \\
\hline Erythritol & 122.10 & $0.928 \pm 0.001$ \\
\hline Xylitol & 152.15 & $0.931 \pm 0.002$ \\
\hline Sorbitol & 182.17 & $0.944 \pm 0.002$ \\
\hline Maltitol & 344.31 & $0.960 \pm 0.000$ \\
\hline Isomalt & 362.32 & $0.961 \pm 0.001$ \\
\hline
\end{tabular}

*Data obtained from the supplier (Nutramax, Catanduva, São Paulo, Brazil).

The kinetics of osmotic dehydration were measured for each osmotic agent until 2 hours with samples obtained in pre determinate periods (15, 30, 45, 60, 90 and $120 \mathrm{~min}$ ). After removal from the solution, each sample was immersed in a cold water bath for 20 seconds to stop the dehydration process. Finally, they had their surface carefully dried with absorbent paper.

The moisture content was determined in a vacuum drying oven at $70{ }^{\circ} \mathrm{C}$ until constant 
weight (A.O.A.C., 2002). The water activity determination was performed with the aid of Aqualab equipment (model CX-2T, Decagon Devices Inc., Pullman, WA, EUA). Water loss (WL) and solid gain (SG) were calculated in accordance with Equations (1-2), respectively.

$$
\begin{aligned}
& W L[\%]=\frac{X_{0} M_{0}-X_{f} M_{f}}{M_{0}} 100 \\
& S G[\%]=\frac{\left(M_{f} x_{s f}-M_{0} x_{s 0}\right)}{M_{0}} 100
\end{aligned}
$$

The experimental data were used to determine the effective water and solid diffusion coefficients according to Fick's law of diffusion. The samples were considered as semi-infinite plates of thickness, 2L. The internal transference of moisture is unidirectional, based on Equation 3 (Crank, 1975):

$$
\frac{\partial X}{\partial t}=\frac{\partial X}{\partial z}\left(D_{e f f} \frac{\partial X}{\partial z}\right)
$$

The initial conditions are as follows: the $\mathrm{D}_{\text {eff }}$ is a constant, and there is a uniform distribution of the initial amounts of moisture and solids. The boundary conditions are as follows: the superficial moisture and solids content is constant and equal at equilibrium $\left(\mathrm{X}_{\mathrm{e}}\right)$ and there is no external resistance to water exit or shrinkage of the samples during osmotic dehydration (Corrêa et al., 2010). Considering the initial and boundary conditions, Equation 3 is resolved as Equation 4, for effective diffusivity of water or solids ( $\left.\mathrm{D}_{\mathrm{eff} w / \mathrm{s}}\right)$ :

$$
\frac{\left(X-X_{e}\right)}{\left(X_{0}-X_{e}\right)}=\frac{8}{\pi^{2}} \sum_{n=0}^{\infty} \frac{1}{(2 n+1)^{2}} \exp \left[\frac{-(2 n+1)^{2} \pi^{2} D_{e f f w / s} t}{4 L^{2}}\right]
$$

The calculations were carried out using a nonlinear estimation procedure by the software Statistica for Windows 8.0® from StatSoft, Inc. (Tulsa, OK, USA). The fitting of the model was verified by the coefficient of determination $\left(\mathrm{r}^{2}\right)$ and standard error estimation (SE). The statistical analyses of the diffusivity coefficients were calculated using the Tukey test $(p<0.05)$ to compare the means.

\section{RESULT AND DISCUSSION}

\subsection{Kinetics of Mass Transfer}

The analysis of the solid gain (SG) rates showed that mass transfer was attenuated after 


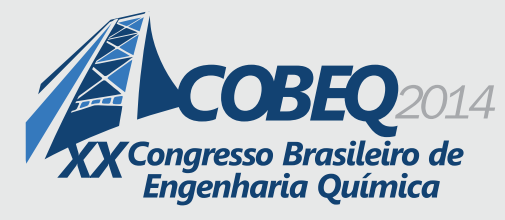

19 a 22 de outubro de 2014

Florianópolis/SC

the first hour of osmotic treatment (Figure 1). Similar behaviour was observed in other OD studies e.g., Maldonado et al. (2008) with yacon in sucrose solution $40{ }^{\circ} \mathrm{B}$ ). The different SG obtained for different osmotic agents can be attributed to the size of their molecules. The ones with high molecular weight are more likely to be retained on the surface of the tissue, resulting in low SG. On the other hand, smaller molecules diffuse more easily through the product matrix (Chauhan et al., 2011). Samples treated with erythritol stood out due to their SG by the end of the OD process $(11.62 \pm 1.15 \%)$. This result can be attributed to the low molar weight of erythritol in relation to the other osmotic agents used in this study (Table 1). Lower SG were observed for samples treated with maltitol and isomalt, $5.50 \pm 0.46 \%$ and $7.40 \pm 0.62 \%$, respectively. Samples subjected to treatments with sorbitol and xylitol showed intermediate SG $(9.62 \pm 1.26 \%$ and $9.62 \pm 0.81 \%$, respectively). The same relationship was observed by Sritongtae et al. (2011) in the osmotic dehydration of cantaloupe with sorbitol and sucrose. They observed higher SG in sorbitol solution due to their smaller molecular size.

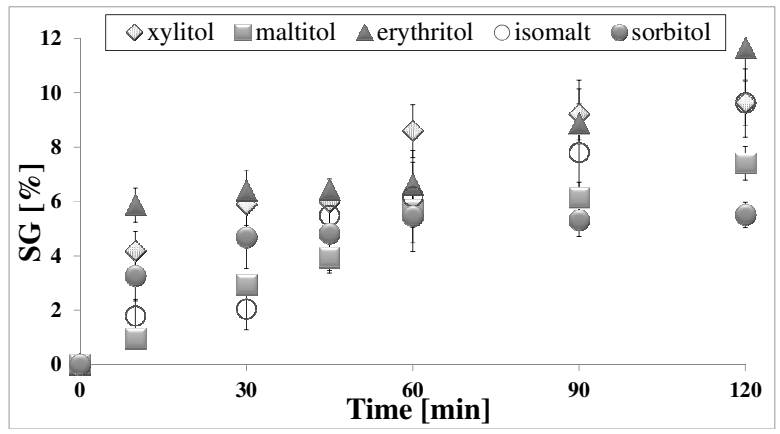

Figure 1 - Kinetics of solid gains of yacon slices in OD with different polyols.

According to Corrêa et al. (2010), the lower the SG, the better the preservation of the original characteristics of the food. Therefore, the minimisation of SG during OD is highly desirable. Hence, the use of erythritol solutions has a distinct disadvantage in food preservation as erythritol carries out to high levels of SG in OD processes.

Similarly to SG, the water loss (WL) of osmodehydrated yacon slices increased in the first hour, with a tendency to equilibrium after this period. This trend was observed for all the different polyols tested The more pronounced rate of WL of the samples was driven by the higher chemical potential gradient between the sample and the solution. At the end of the OD treatment with different polyols, WL was more pronounced in samples treated with solutions of sorbitol $(66.95 \pm 1.08 \%)$, erythritol $(62.43 \pm 1.96 \%)$ and xylitol $(61.94 \pm 1.88 \%)$ and smaller in samples treated with solutions of isomalt $(53.25 \pm 2.67 \%)$ and maltitol $(50.29 \pm 4.01 \%)$. The same relationship was observed by Ferrari and Hubinger (2008) in osmotic dehydration of melons in solutions of maltose and sucrose. 


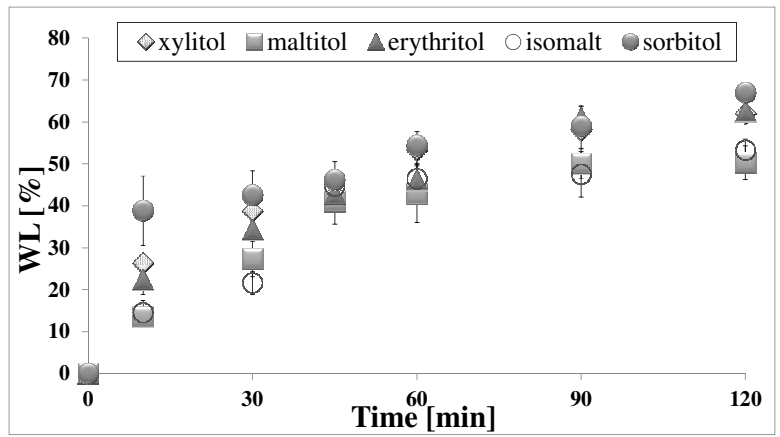

Figure 2 - Kinetics of water loss of yacon slices during OD by different polyols.

The water activity $\left(a_{w}\right)$ of yacon slices during the osmotic dehydration process with different polyols is shown in Figure 3. As observed for the other parameters, the first hour of treatment resulted in the greatest reduction of $a_{w}$. Higher reduction of $a_{w}$ was observed for samples treated with lower $\mathrm{a}_{\mathrm{w}}$ solutions (Table 1). Thus, a greater reduction of $\mathrm{a}_{\mathrm{w}}$ was observed in solutions with the lower molecular weight solutes: erythritol $(0.936 \pm 0.002)$, xylitol $(0.937 \pm$ $0.004)$ and sorbitol $(0.956 \pm 0.001)$. These solutions also showed higher WL and SG than solutions with higher molecular weight solutes. The $\mathrm{a}_{\mathrm{w}}$ is function of the disponible water and the soluble solids, what could be related to the WL and SG. Samples immersed in solutions with the smaller molecular weight solutes, maltitol and isomalt, achieved lower reduction in $a_{w}$ ( $0.964 \pm 0.005$ and $0.973 \pm 0.002$, respectively). The reduction of $\mathrm{a}_{\mathrm{w}}$ followed the same trend as seen for the WL of the samples and correlated with the molecular size of the osmotic agent. However, it is noteworthy that the $\mathrm{a}_{\mathrm{w}}$ of the solutions are directly related to the molar mass of the solute it is composed of. The $\mathrm{a}_{\mathrm{w}}$ of the osmotic solution decreases as the molecular weight of the solute is reduced (Ferrari and Hubinger, 2008).

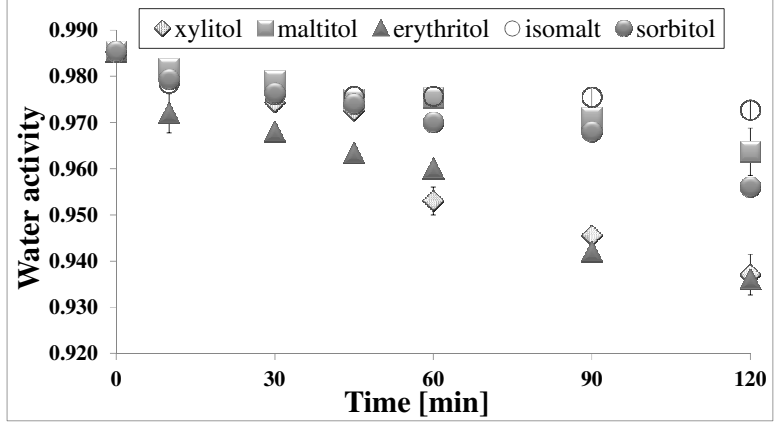

Figure 3 - Kinetics of water activity reduction of yacon slices during OD by different polyols. 


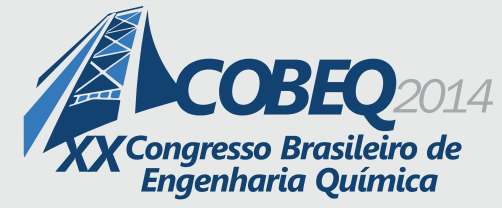

19 a 22 de outubro de 2014

Florianópolis/SC

\subsection{Effective Diffusion Coefficients of Water and Solids}

The values effective diffusion coefficients of water $\left(D_{\text {effw }}\right)$ and solids $\left(D_{\text {effs }}\right)$ obtained for the osmotic processing of yacon slices (Table 2) were found to be in the range of $10^{-10} \mathrm{~m}^{2} \mathrm{~s}^{-1}$. These values are in agreement with literature values (Allalli et al., 2010; Uribe et al., 2011). It could be stated that the fitness of the model was not so high ( $\mathrm{r}^{2}$ and SE values). However, the effective diffusivity identified the kinetics of the process and was adequate for quantifying the influence of factors considered, the influence of the different osmotic agents.

Table 2 - Analysis of variance for the effective diffusion coefficients of water $\left(D_{\text {effw }}\right)$ and for solids $\left(\mathrm{D}_{\mathrm{effs}}\right)$ in yacon slices during osmotic dehydration with different osmotic agents

\begin{tabular}{|l|l|l|l|l|l|l|l|l|}
\hline $\begin{array}{l}\text { Osmotic } \\
\text { agent }\end{array}$ & $\begin{array}{l}\mathrm{D}_{\text {effw }} \times 10^{-10} \\
{\left[\mathrm{~m}^{2} \mathrm{~s}^{-1}\right]}\end{array}$ & $\mathrm{SE}$ & $\mathrm{r}^{2}$ & $\mathrm{WL}_{\infty}[\%]$ & $\begin{array}{l}\mathrm{D}_{\text {effs }} \mathrm{x} 10^{-10} \\
{\left[\mathrm{~m}^{2} \mathrm{~s}^{-1}\right]}\end{array}$ & $\mathrm{SE}$ & $\mathrm{r}^{2}$ & $\mathrm{SG}_{\infty}[\%]$ \\
\hline Xylitol & $4.17 \pm 0.49^{\mathrm{a}}$ & 0.04 & 0.98 & $64.94 \pm 1.88$ & $1.96 \pm 0.27^{\mathrm{a}}$ & 0.03 & 0.97 & $19.61 \pm 3.58$ \\
\hline Sorbitol & $2.89 \pm 0.05^{\mathrm{b}}$ & 0.08 & 0.96 & $67.15 \pm 2.40$ & $1.20 \pm 0.18^{\mathrm{b}}$ & 0.05 & 0.96 & $21.40 \pm 0.99$ \\
\hline Erythritol & $2.58 \pm 0.73^{\mathrm{bc}}$ & 0.03 & 0.96 & $68.03 \pm 1.69$ & $2.24 \pm 0.09^{\mathrm{a}}$ & 0.06 & 0.96 & $19.61 \pm 1.42$ \\
\hline Maltitol & $1.82 \pm 0.71^{\mathrm{cd}}$ & 0.06 & 0.94 & $57.98 \pm 2.85$ & $1.39 \pm 0.09^{\mathrm{b}}$ & 0.04 & 0.96 & $15.73 \pm 2.60$ \\
\hline Isomalt & $1.25 \pm 0.18^{\mathrm{d}}$ & 0.05 & 0.96 & $53.83 \pm 1.15$ & $0.90 \pm 0.11^{\mathrm{c}}$ & 0.04 & 0.96 & $18.80 \pm 1.97$ \\
\hline
\end{tabular}

Values followed by the same letters are not significantly different according to the Tukey test $(\mathrm{p}<0.05)$.

The molecular weight of the osmotic agent directly affects the ability of the solute and the water to diffuse through the product matrix. A larger effective diffusivity coefficient for water $\left(D_{\text {effw }}\right)$ and solids $\left(D_{\text {effs }}\right)$ was observed in samples treated with lower molecular weight solutes. The $D_{\text {effw }}$ results agree with the results of the WL and $a_{w}$, where the major water losses were observed in samples treated in solutions with a greater chemical potential gradient or in solutions with a lower water activity (Table 1). Furthermore, the $\mathrm{D}_{\text {effs }}$ results are in agreement with typical SG trends; lower molar weight solutes diffuse quickly through the yacon slice matrix.

\section{CONCLUSIONS}

For all the tested polyols, the WL and the SG increased in the first hour with a tendence to the equilibrium after this period.

Osmotic agents of lower molar weight provided greater WL and reduction in $\mathrm{a}_{\mathrm{w}}$ than higher molar weight agents.

Lower SG was observed in samples treated with isomalt and maltitol. Nevertheless, these agents have not been the most effective agents in reducing $\mathrm{a}_{\mathrm{w}}$ and WL during the osmotic process. Samples treated with erythritol reached the highest SG. Sorbitol and xylitol were the most effective osmotic agents and are recommended for the osmotic treatment of yacon slices. 
Sorbitol and xylitol reduced the $\mathrm{a}_{\mathrm{w}}$ and the WL, and they had intermediary values for the $\mathrm{D}_{\text {effw }}$ and $\mathrm{SG}$ from 60 minutes to osmotic process.

\section{ACKNOWLEDGEMENTS}

The authors gratefully acknowledge CAPES, FAPEMIG and CNPq for financial support.

\section{NOMENCLATURE}

$\begin{array}{ll}a_{\mathrm{w}} & \text { Water activity } \\ \mathrm{D}_{\text {eff }} & \text { Effective diffusivity } \\ \mathrm{D}_{\text {effs }} & \text { Effective diffusivity of solids } \\ \mathrm{D}_{\text {effw }} & \text { Effective diffusivity of water } \\ \text { FOS } & \text { Fructooligosaccharides } \\ \mathrm{M}_{0} & \text { Initial weight of sample }[\mathrm{Kg}] \\ \mathrm{M}_{\mathrm{f}} & \text { Final weight of sample }[\mathrm{Kg}] \\ \text { OD } & \text { Osmotic dehydration } \\ \text { SG } & \text { Solid gain }\end{array}$

$\begin{array}{ll}\mathrm{WL} & \text { Water loss } \\ \mathrm{X} & \text { Moisture or solids content at instant } \mathrm{t} \\ \mathrm{X}_{\mathrm{eq}} & \text { Moisture or solids content at equilibrium } \\ \mathrm{X}_{0} & \text { Initial moisture content }[\mathrm{Kg} / 100 \mathrm{Kg}] \\ \mathrm{X}_{\mathrm{f}} & \text { Final moisture content }[\mathrm{Kg} / 100 \mathrm{Kg}] \\ \mathrm{X}_{\mathrm{s} 0} & \text { Initial solid content }[\mathrm{Kg} / 100 \mathrm{Kg}] \\ \mathrm{X}_{\mathrm{sf}} & \text { Final solid content }[\mathrm{Kg} / 100 \mathrm{Kg}] \\ \mathrm{z} & \text { Generic directional coordinate } \\ \mathrm{L} & \text { Characteristic lenght }\end{array}$

\section{REFERENCES}

A.O.A.C. 2002. Official Methods of Analysis of the Association of Official Analytical Chemists. 17th edn. Gaithersburg: William Horwitz, 2009.

ALLALI, H.; MARCHAL, L.; VOROBIEV, E. Blanching of Strawberry by Ohmic Heating: Effects on the Kinetics of Mass Transfer during Osmotic Dehydration. Food Bioprocess Technol., v. 3 (3), p. 406-414, 2010.

CHAUHAN, O. P.; SINGH, A.; SINGH, A.; RAJU, P. S.; BAWA, A. S. Effects of osmotic agents on colour, textural, structural, thermal, and sensory properties of apple slices. Int. J. Food Prop., v. 14 (5), p.1037-1048, 2011.

CORRÊA, J.; PEREIRA, L.; VIEIRA, G.; HUBINGER, M. Mass transfer kinetics of pulsed vacuum osmotic dehydration of guavas. J. Food Eng., v. 96 (4), p.498-504, 2010.

CRANK, J. The mathematics of diffusion. (2 ${ }^{\text {nd }}$ ed.). New York: Oxford University Press, 1975.

FERRARI, C. C.; HUBINGER, M. D. Evaluation of the mechanical properties and diffusion coefficients of osmodehydrated melon cubes. Int. J. Food Sci. Tech., 43 (11), p. 2065-2074, 2008.

FERRARI, C. C.; ARBALLO, J. R.; MASCHERONI, R. H.; HUBINGER, M. D. Modelling of mass transfer and texture evaluation during osmotic dehydration of melon under vacuum. Int. J. Food Sci. Tech., v. 46 (2), p. 436-443, 2011. 


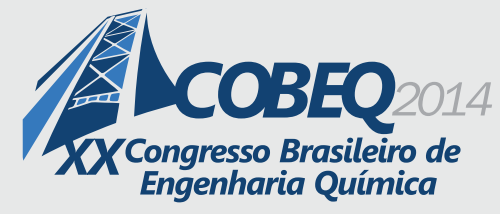

LABUZA, T. P. Oxidative changes in foods at low and intermediate moisture levels. In: Duckworth, R. B. Water relations of foods. ed. New York: Academic Press, 455p., 1975.

LAGO, C. C.; BERNSTEIN, A.; BRANDELLI, A.; NOREÑA, C. P. Z. Characterization of Powdered Yacon (Smallanthus sonchifolius) Juice and Pulp. Food Bioprocess Technol., v. 5 (6), p.2183-2191, 2012.

LENART, A.; DABROWSKA, R. Kinetics of osmotic dehydration of apples with pectin coatings. Drying Tech., v. 17 (7-8), p. 1359 - 1373, 1999.

MALDONADO, S.; SANTAPAOLA, J. E.; SINGH, J.; TORREZ, M.; GARAY, A. Cinética de la transferência de massa durante la deshidratación osmótica de yacon (Smallanthus sonchifolius). Cien. Tecnol. Alim., v. 28 (1), p. 251-256, 2008.

MERCALI, G. D.; TESSARO, I. C.; NOREÑA, C. P. Z.; MARCZAK, L. D. F. Mass transfer kinetics during osmotic dehydration of bananas (Musa sapientum, shum.). Int. J. Food Sci. Tech., v. 45 (11), p. 2281-2289, 2010.

MUJUNDAR, A.; LAW, C. Drying Technology: Trends and Applications in Postharvest Processing. Food Bioprocess Technol., v. 3 (6), p. 843-852, 2010.

PEREIRA, J. A. R.; BARCELOS, M. F. P.; PEREIRA, M. C. A.; FERREIRA, E. B. Studies of chemical and enzymatic characteristics of Yacon (Smallanthus sonchifolius) and its flours. Food Sci Technol., v. 33 (1), p. 75-83, 2013.

SRITONGTAE, B.; MAHAWANICH, T.; DUANGMAL, K. Drying of osmosed cantaloupe: effect of polyols on drying and water mobility. Drying Tech., v. 29 (5), p.527-535, 2011.

REIS, F. R.; LENZI, M. K.; MUÑIZ, G. I. B.; NISGOSKI, S.; MASSON, M. L. Vaccum Drying Kinetics of Yacon (Smallanthus sonchifolius) and Effect of Process Condictions on Fractal Dimension and Rehydration Capacity. Drying Tech., v. 30 (1), p.13-19, 2012.

URIBE, E.; MIRANDA, M.; VEGA-GÁLVEZ, A.; QUISPE, I.; CLAVERÍA, R.; SCALA, K. Mass Transfer Modelling During Osmotic Dehydration of Jumbo Squid (Dosidicus gigas): Influence of Temperature on Diffusion Coefficients and Kinetic Parameters. Food Bioprocess Technol., v. 4 (2), p. 320-326, 2011.

VIANA, A. D.; CORRÊA, J. L. G.; JUSTUS, A. Optimisation of the pulsed vacuum osmotic dehydration of cladodes of fodder palm. International Journal of Food Science \& Technology, v. 49(3), p. 726-732, 2014. 